\title{
Polydactyly Nagoya, Pdn: A New Mutant Gene in the Mouse
}

\author{
Ikuo HAYASAKA, Toshio NAKATSUKA, Takaaki FUJII, \\ Ichiro NARUSE* and Sen-ich ODA* \\ Research Laboratories, Nippon Merck-Banyu Co., Ltd., Okazaki 444, \\ and $*$ Research Institute of Environmental Medicine, \\ Nagoya University, Nagoya 464, Japan
}

(Received for publication: December 10, 1979)

\begin{abstract}
A new hereditary polydactyly (gene symbol $P d n$ ) was found in the course of breeding JCL : ICR mice. The genetic analysis indicated that the polydactyly was an autosomal dominant trait. The homozygotes died within two days after birth. The homozygous fetuses or newborn had 1-3 extra-digits both in the fore- and hindlimbs on the preaxial side. They occasionally showed exencephaly, cleft palate, open eyelid, short tibia and fibula or deformed sternum. The heterozygotes had one extra-digit preaxially in the hindlimb and an enlarged first digit of the forelimb which often showed bifurcated distal phalanx. A tab on the postaxial side of the forelimb was found in all homozygotes and in some heterozygotes.
\end{abstract}

This report describes a mutation in mice causing polydactyly. Polydactyly arose in the course of breeding JCL : ICR mice at Research Laboratories, Nippon Merck-Banyu Co., Ltd., Okazaki, Japan in 1977. JCL : ICR male and female mice $\left(F_{0}\right)$ were purchased from CLEA Japan Inc. and bred. Three $\mathrm{F}_{2}$ offspring (2 males and 1 female) out of 13 from an $F_{1}$ female had polydactyly. This anomaly in mice was considered to be genetic in origin, and genetic analysis and morphological observation were conducted.

\section{Materials and Methods}

For the mating test, male mice with polydactyly were crossed to females with polydactyly (cross 1 ) and to normal females (cross 2). Pregnant females were killed on day 18 of pregnancy by cervical dislocation and the uterus was observed in situ for implantation and resorption sites. Fetuses were counted, weighed, sexed and examined for external malformations.

For morphological observations, skeletons of the fetuses, newborn and adults were stained with alcian blue/alizarin red S according to Inouye [2].

\section{Results}

\section{Mating test}

As shown in Table 1, 193 fetuses were obtained from the cross between polydactylous males and polydactylous females (cross 1). Fifty-four fetuses were normal, 82 had one extra-digit in the hindlimb (presumed genotype, $P d n /+$ ) and 57 had more than one extra-digit both in the fore- and hindlimbs (presumed genotype, $P d n / P d n)$. Among 102 fetuses obtained from the cross between polydactylous males and normal females (cross 2), 54 fetuses were normal and 48 had one extradigit in the hindlimb (presumed genotype, $P d n /+)$. No sex difference was found in the frequency of polydactyly. The number 
Table 1. Frequency of polydactylous mice $(P d n)$ on day 18 of gestation

\begin{tabular}{|c|c|c|c|c|c|c|c|c|c|c|c|c|}
\hline (pr & $\begin{array}{l}\text { Female } \\
\text { resumed } \mathrm{g}\end{array}$ & $\begin{array}{l}\times \text { Male } \\
\text { enotype) }\end{array}$ & $\begin{array}{l}\text { No. of } \\
\text { litters }\end{array}$ & male & $\frac{t / t}{\text { female }}$ & total & male & $\frac{P d n /+}{\text { female total }}$ & $\frac{P c}{\text { male } \mathrm{f}}$ & $\frac{/ P d n}{\text { male }}$ & $\frac{n}{\text { total }} N$ & $\begin{array}{l}\text { No. of dead } \\
\text { fetuses }\end{array}$ \\
\hline Cross & $P d n /+$ & $P d n /+$ & 17 & 22 & 32 & $\begin{array}{c}54 \\
28.0 \%)\end{array}$ & 43 & $39 \begin{array}{c}82 \\
(42.5 \%)\end{array}$ & 29 & 28 & $\begin{array}{c}57 \\
(29.5 \%)\end{array}$ & $\begin{array}{c}21 \\
(9.8 \%) *\end{array}$ \\
\hline Cross & $+1+$ & $P d n /+$ & 9 & 27 & 27 & $\begin{array}{c}54 \\
52.9 \%)\end{array}$ & 25 & $23 \quad 48$ & 0 & 0 & 0 & $\begin{array}{c}5 \\
(4.7 \%) *\end{array}$ \\
\hline
\end{tabular}

* Number of dead fetuses/total implants $\times 100$

Table 2. Body weight of polydactylous mice $(P d n)$

\begin{tabular}{|c|c|c|c|c|c|c|}
\hline \multirow{2}{*}{ Genotype } & \multicolumn{2}{|c|}{ Day 18 of gestation } & \multicolumn{2}{|c|}{ At birth } & \multicolumn{2}{|c|}{ At weaning } \\
\hline & male & female & male & female & male & female \\
\hline$+1+$ & $\begin{array}{c}1.50 \pm 0.10 \\
(11)\end{array}$ & $\begin{array}{c}1.45 \pm 0.07 \\
(21)\end{array}$ & $\begin{array}{c}1.79 \pm 0.13 \\
(17)\end{array}$ & $\begin{array}{c}1.71 \pm 0.13 \\
(16)\end{array}$ & $\begin{array}{c}9.84 \pm 2.35 \\
(18)\end{array}$ & $\begin{array}{c}10.67 \pm 1.95 \\
(12)\end{array}$ \\
\hline$P d n /+$ & $\begin{array}{c}1.56 \pm 0.11 \\
(24)\end{array}$ & $\begin{array}{c}1.48 \pm 0.10 \\
(22)\end{array}$ & $\begin{array}{c}1.87 \pm 0.09 \\
(18)\end{array}$ & $\begin{array}{c}1.81 \pm 0.15 \\
(20)\end{array}$ & $10.79 \pm 2.79$ & $10.75 \pm 2.08$ \\
\hline$P d n / P d n$ & $\begin{array}{c}1.63 \pm 0.08 * * \\
(17)\end{array}$ & $\begin{array}{l}1.54 \pm 0.15^{*} \\
(18)\end{array}$ & $1.81 \pm \frac{ \pm}{(5)} 0.12$ & $\begin{array}{l}1.95 \\
(1)\end{array}$ & - & - \\
\hline
\end{tabular}

The values are average \pm S. D.

The number in parentheses represents offspring examined.

* Significantly different from $+/+$ offspring at $\mathrm{p}<0.05$ ( $\mathrm{t}$-test)

** Significantly different from $+/+$ offspring at $\mathrm{p}<0.01$ (t-test)

of dead fetuses was within the normal range of JCL : ICR $(6.5-10.9 \%$ in our laboratory). The results suggested that this polydactyly in mice was caused by an autosomal dominant gene. The results of chi-square analysis (cross $1: \chi^{2}=4.451$, $0.1<\mathrm{P}<0.2$; cross $2: \chi^{2}=0.353,0.5<\mathrm{P}$ $<0.7)$ are in accordance with this hypothesis.

We herewith propose Polydactyly Nagoya as the name of the new mutant gene and $P d n$ as its symbol.

\section{Morphological observation}

A number of homozygous $(P d n / P d n)$ newborn from heterozygous parents may have been cannibalized just after birth, since the number of $P d n / P d n$ newborn observed at birth was less than expected. The live $P d n / P d n$ newborn died within two days after birth. Heterozygous $(P d n$ /+) mice were fully viable and bred freely. As shown in Table 2, $P d n / P d n$ fetuses were significantly heavier than $+/+$ fet- uses on day 18 of gestation.

$P d n / P d n$ fetuses and newborn had 2 or 3 extra-digits in the forelimb and 1-3 extra-digits in the hindlimb on the preaxial side. Fusion between extra-digits and between extra-digit and neighboring digits was often observed. A tab appeared on the postaxial side of the forelimb (Figs. 1 and 2). In $P d n / P d n$ mice, exencephaly, cleft palate and open eyelid were found in $20.7 \%, 12.1 \%$ and $12.1 \%$, respectively. The $P d n /+$ fetuses and newborn had an enlarged first digit, often had a tab on the postaxial side of the forelimb (Fig.4), and showed one extra-digit on the preaxial side of the hindlimb (Fig. 5). The tab of the forelimb regressed and the extra-digit of the hindlimb became rudimentary when the mice grew up.

Skeletal examination of $P d n / P d n$ fetuses revealed that polydactyly both in the foreand hindlimbs was duplicated and bifurcated metatarsal/metacarpal in type (Fig. $3)$. Triphalangia in the forelimb was 
observed in half of the $P d n / P d n$ fetuses and newborn and in all of the $P d n / P d n$ in the hindlimb. The carpus and tarsus were distorted and fused. The radius and ulna were normal in length but the tibia and fibula were shorter than those of $P d n /+$ or $+/+$ mice. Most of the $P d n / P d n$ mice had a bifurcation of the manubrium sterni. In $P d n /+$ fetuses and newborn, the phalanges of the enlarged first digit of the forelimb were thick and about a half of the distal phalanx was bifurcated. However, these thickened phalanges and bifurcated phalanx were not found in the adult. The extra-digit on the preaxial side of the hindlimb was not stained with alcian blue and alizarin red $S$ in most cases of $P d n /+$ fetuses and newborn, but it was stained as a small red lump in the adult.

\section{Discussion}

At least 17 mutant genes which produce polydactyly in mice are known and eleven of them are reported to be dominant [Mouse News Letter No. 60,1979]. The dominant gene such as $D h, l x, l s t$ and $l u$ causes preaxial polydactyly but these mutants involve oligodactyly and severe hemimelia, which did not appear in a new mutant $(P d n)$ [1]. The phenotypes of extra-toes $(X t)$ [3] are similar to those of the $P d n$ mice observed in this experiment. $X t$ is situated in linkage group XIV, near the gene for crinkled (cr) [4]. The first digit of the forelimb in $X t /+$ mice is enlarged or duplicated and a small lump often appears at the base of digit $\mathrm{V}$ of the forelimb. In the hindlimb of heterozygotes $(X t /+)$ a 6 th or even a 7 th toe is found preaxially. The homozygotes die at birth or in utero with a wide range of abnormalities. These include paddleshaped feet with up to 8 digits, hemimelia, edema, exencephaly, hydrocephaly and microphthalmia as well as abnormalities of the sensory hair, sternum, skull and cervical vertebrae [3].

In the present experiment, we examined the new mutant mice $(P d n)$ for external and skeletal abnormalities and found polydactyly similar to that of the extra-toes $(X t)$, hemimelia in the hindlimb, cleft palate, open eyelid and the deformed sternum. However, $P d n$ gene did not produce edema and abnormalities of the sensory hair and cervical vertebrae.

Further genetic analyses and morphological observations of this mutant will be conducted.

\section{Acknowledgements}

We wish to thank Prof. Y. Kameyama and Dr. K. Hoshino for their valuable discussion.

\section{References}

[1] Grüneberg, H. (1963). Disorders of the appendicular skeleton I. In The Pathology of Development, pp. 190-213, Grüneberg,H.(edit). Blackwell Scientific Publications, Oxford.

[2] Inouye, M. (1976). Differential staining of cartilage and bone in fetal mouse skeleton by alcian blue and alizarin red S. Cong. Anom., 16, 171-173.

[3] Johnson, D. R. (1967). Extra-toes : a new mutant gene causing multiple abnormalities in the mouse. J. Embryol. Exp. Morph., 17, 543-581.

[4] Lyon, M. F., Morris, T., Searle, A. G. and Butler, J. (1967). Occurrences and linkage relations of the mutant 'extra-toes' in the mouse. Genet. Res. Camb., 9. 383-385. 


\section{突然変異によるマウス多指症 $(P d n)$ について}

早坂郁夫・中塚敏夫・藤井孝朗

*成瀨一郎.*織田銑一

日本メルク萬有株式会社研究所

*名古屋大学環境医学研究所

$\mathrm{JCL}$ : ICR マウスに 遺伝性多指症が 発見されたので その遺伝様式および形質の特徵を調べた。交配実験より このミュータントは常染色体性優性遺伝子によって支配 されていることが判明した。ホモ個体は生後 2 日以内に 死亡したが, 生存胎仔あるいは新生仔は前後の軸前側に $1 \sim 3$ 本の過剩指および軸後側に痕跡状過剩指を有して いた。へテロ個体では後肢の軸前側に 1 本の過剩指がみ
られた。またへテロ個体の前肢では第 1 指が肥大し，そ のらち約半数に末節骨の分枝が観察され, 軸後側にはし ばしば痕跡状過剩指がみられた。これらのことよりこ のマウスの多指症を Polydactyly Nagoya, $P d n$ と 命名した。な打木モ個体は外脳症 $(20.7 \%)$, 口蓋裂 $(12.1 \%)$, 眼䀫開存 $(12.1 \%)$, 後肢の短肢 $(100 \%)$ および胸骨の異常（100\%）を伴っていた。

\section{Explanation of Figures}

Fig. 1 Ventral view of the left forelimb of $P d n / P d n$ fetus on day 18 of gestation. Three extra-digits on the preaxial side and $\operatorname{tab}(\uparrow)$ on the postaxial side.

Fig. 2 Ventral view of the left hindlimb of $P d n / P d n$ fetus on day 18 of gestation. Three extra-digits on the preaxial side.

Fig. 3 Dorsal view of the left hindlimb of $P d n / P d n$ newborn (differential staining of cartilage and bone). Complete preaxial polydactyly with triphalangia.

Fig. 4 Ventral view of the right forelimbs of $P d n /+$ (right) and +/+ (left) fetuses on day 18 of gestation. Enlarged pollex and tab on the postaxial side in the $P d n /+$ fetus.

Fig. 5 Ventral view of the left hindlimb of $P d n /+$ fetus on day 18 of gestation. Extra-digit on the preaxial side. 

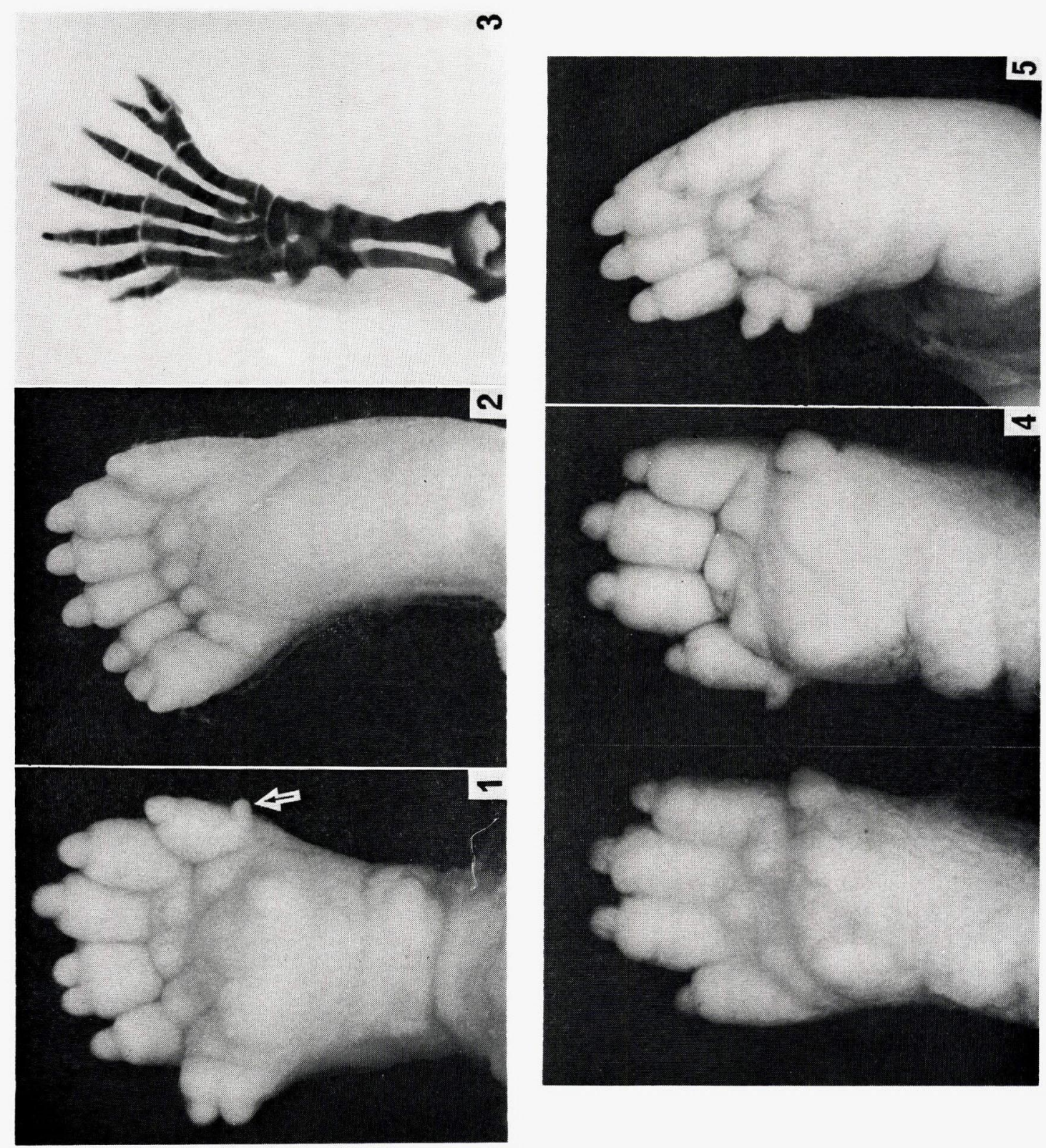